\title{
ONLINE CSR DISCLOSURES OF PHILIPPINES' TOP 30 PUBLICLY-LISTED COMPANIES
}

\author{
Jesus P. Briones* \\ University of Batangas
}

\begin{abstract}
This study investigated the extent of online CSR disclosures of the top 30 publicly-listed companies in the Philippines. Employing the content analysis approach, the study determined the CSR index of each company using Khasharmeh \& Desoky's approach (2013). Findings revealed that all the companies have stand alone section in their corporate websites where CSR activities are disclosed with "CSR" or "Sustainability" as the most popular heading. The study also found out that among the four CSR category themes, information related to community involvement, and environment themes are generally prioritized compared with the other category themes. The subject-companies have below average level of disclosure with overall disclosure index of 27.93. The study concluded that online CSR disclosures significantly varies along the four category themes while length of business of operation is considered as the only determinant of CSR disclosures among the firm attributes covered in the study.
\end{abstract}

Keywords: Online CSR disclosures; Content analysis; Publicly-listed companies; Philippine Stock Exchange; Corporate social responsibility

Received: 8 May 2019

Accepted: 30 December 2019

\section{INTRODUCTION}

Nowadays, the use of internet considerably enhances a corporation's ability to convey its strategies, practices and other relevant information directly to its stakeholders. The popularity of internet as fundamental mechanism of communication has made companies to consider their websites as a crucial element for establishing corporate image. Online disclosures through their websites have prompted companies to communicate their corporate social responsibility (CSR) activities to a large number of users (Moreno \& Capriotti, 2009). CSR online disclosures refers to the provision of information of how a particular firm aims to provide solutions for its improved accountability affecting its stakeholders especially on environmental and societal issues. Considering that firms have to become more responsible and that their activities have to focus to benefit various stakeholders, CSR is regarded as a means by which firms improve their image and maintain their license to operate.

CSR disclosures through the corporation's website is a gesture of showing transparency of the business to the society and can be considered an important aspect of good corporate governance practice. The conduct of this study is of primordial interest considering the current unregulated

\footnotetext{
* Corresponding author: Director, Publications, Research, Linkages, \& Liaison, University of Batangas, Hilltop, Batangas City, Philippines; Telephone Number: +639081429272; E-mail: jesus.briones@ub.edu.ph; jpbriones1961@gmail.com
} 
practice of the companies using their official websites as the main medium in disclosing their CSR reports to their stakeholders. Recent development in the Philippines indicates that the Securities and Exchange Commission (SEC) will require publicly listed companies starting year 2020 to submit their sustainability reports which will indicate their responsibility of taking care of human, social and environmental capitals (Business World, 2019). Since this study, to the best knowledge of the author, is the first local study of its kind, regulatory authorities and other concerned agencies could make use of the findings of this study as baseline data in drawing up plans and policies on how online CSR disclosures by any Philippine companies can be regulated.

There are already empirical studies on assessing the CSR disclosures in several countries along the different industry sectors but there has not been a study focused singly on Philippine companies. Among the European countries, recent studies on online CSR disclosures were conducted in Portugal (Branco \& Rodrigues, 2006), in Croatia (Grudic Kvasic, et al., 2016), in Belgium (Pozniak et al., 2011), in Finland (Lakatos et al., 2012), and in Spain (Moreno \& Caprioritti, 2009; Bravo et al., 2012; Garcia et al., 2016). In Middle East, a similar research has been done in Egypt (Elsayed, 2010). There are also several studies conducted in the Asian countries, such as in Malaysia (Rahim, 2016; Amran, 2012; Hassan et al., 2012; Ghazali, 2007; Haji, 2013; Said et al., 2009; Homayoun et al., 2012), in India (Sanil \& Ramakrishnan, 2015), in Japan (Fukukawa \& Moon, 2004), and in Bangladesh (Rouf, 2011; Sobhani et al., 2012). Some studies not only examined online CSR disclosures across countries but compared them as well. As an example, Chapple and Moon (2005) investigated the CSR website reporting in seven Asian countries which include India, Indonesia, Malaysia, Philippines, Singapore, South Korea, and Thailand. The study revealed that their practices do vary considerably among countries. The study revealed that one common practice among Philippine companies is their engagement through a variety of systematic modes of community involvement, particularly through partnerships and foundations. This explains why their report on community involvement is high among the seven Asian countries but their report along the areas of production processes and employee relations is one of the lowest. The study of Khasharmeh and Desoky (2013) revealed similar findings when they investigated the online CSR disclosures among six Gulf Cooperation Council countries (Kingdom of Bahrain, Kingdom of Saudi Arabia, Kuwait, Oman, Qatar, and the United Arab Emirates. Similarly, the study of Wanderly et al. (2008) analyzed the websites of 127 corporations from emerging countries such as Brazil, Chile, China, India, Indonesia, Mexico, Thailand, and South Africa where they found out that both country of origin and industry sector have a significant influence over CSR information disclosure on the web. Nonetheless, studies on online CSR disclosure in developing countries are still scarce, thus this study in the Philippine context is important considering how companies nowadays are giving importance to their CSR activities as part of their corporate strategies.

This study which examined the online CSR disclosures of top publicly-listed companies in the Philippines aimed to relate the extent of CSR communication on their websites with their firm attributes. This study was based on stakeholder theory of CSR which considers the organization's commitment to operate in an economically and environmentally sustainable manner while recognizing the interest of its stakeholders in order to build reputation and achieve positive operating results (Porter \& Kramer, 2006). Erdiaw-Kwasie et al. (2017) confirmed that the company's stakeholder orientation describes the company's ability to attend to the interests of all its relevant stakeholders. Along this context, CSR reporting can be considered as a function of gaining and maintaining organizational legitimacy. The present study specifically focused on 
community, employees, customers, and society in general as stakeholders where CSR disclosures on information related to community involvement, employees, products, and environment are highlighted.

\section{LITERATURE REVIEW}

In order to accomplish the objective of the study, a series of research hypothesis was formulated. Various findings from previous studies, together with what has been discussed above, were used in formulating hypothesis for the current study. In the light of these issues, research hypotheses were developed based on the following discussion.

First, on the issue of how listed companies disclose their activities along CSR dimensions, Khasharmeh and Desoky (2013) found out that there is considerable variation among companies in their disclosures along the different CSR dimensions (environmental, employee, community and social involvement, and product). In a similar vein, Castelo and Lima (2006) observed difference in the importance tied by companies to the different dimensions of CSR. This led to the hypothesis that:

H1: Reporting of CSR activities varies along the different disclosure dimension/ category theme

Second, looking into the relationship of the industry sector of the listed companies and the extent of CSR disclosures, several studies were reviewed. Among these studies, two groups of researchers (Bonson \& Escobar, 2002; Bayoud et al., 2012) revealed a positive influence of industry sector on the quantity of information provided by the company. Companies from specific sectors must communicate on certain aspects in order to improve their image. This led to the hypothesis that:

H2: Industry sector of the reporting company influences their CSR disclosure index score

Third on the list is the length of business operation as measured by the number of years since the firm's inception. Several researchers (Hamid, 2004; Branco \& Rodriguez, 2006) found out a positive relation between company's age and its level of CSR information disclosure. This led to the hypothesis that:

\section{H3: Length of business operation influences CSR disclosure index score}

Fourth, this research tried to relate the number of years listed with reputable stock exchange agency and the extent of CSR disclosures. This study presumed that the listed companies are more notorious than non-listed companies. Branco and Rodriguez (2006) narrated that the more famous a company, being listed, the higher the need for justifying its existence through CSR communication. Hamid (2004) found a positive correlation between the listing status of a company and its level of CSR information disclosure. This led to the hypothesis that:

H4: Number of years listed influences CSR disclosure index score

Lastly, this study intended to determine if size of the firm is a factor on how listed companies disclose CSR information. Most of the studies found that size of a firm does affect the level of 
CSR disclosure of companies. Suwaidan (2004) and Barako et al. (2006) revealed that the larger the firm, the more likely it will make voluntary CSR disclosures. Similarly, Mohd Ghazali (2007) concluded a positive relationship between company's size and the extent of CSR disclosure. In this study, market capitalization was considered to determine the size of the firm. This led to the hypothesis that:

\section{H5: Market capitalization influences CSR disclosure index score}

Determining how the CSR activities of publicly-listed companies are reported is important since the findings of the study would make the stakeholders more aware of how socially and environmentally responsible these companies are. The information disclosed in their websites, if properly analyzed, can serve as one of their yardsticks in choosing the companies that they would be dealing business with. On the other hand, the management of these companies would realize that online CSR disclosures, in addition to the traditional paper-based reporting, is a timely and more useful tool as they achieve their business goals and objectives.

\section{METHODOLOGY}

The study population consisted of the top 30 publicly-listed companies in 2018 (ASEAN Up, 2019) which were quoted from the Philippines Stock Exchange (PSE), the agency in charge of ensuring proper market conditions for the trading of the country's stocks. The main index for PSE is the PSEi, which is composed of a fixed basket of these top 30 publicly-listed companies. The PSEi measures the relative changes in the free float-adjusted market capitalization of these 30 largest and most active common stocks listed at the PSE. These listed companies in the PSE were selected based on a specific set of public float, liquidity and market capitalization criteria. For the purpose of this study, the websites of each of these 30 largest corporations in the Philippines (Appendix A) were evaluated relative to their CSR related information.

The study used content analysis as a technique to identify and describe the CSR disclosure practices of the subject-companies. Content analysis, being a dominant method to examine online CSR disclosure (Patten, 2002), is a tool used to determine the presence of certain words, concepts, themes, phrases, characters or sentences within text or texts and to quantify this presence in an objective manner. Thus, content analysis is a scientific study of the content of communication with reference to the meanings, contexts and intentions contained in messages. In order to provide an evaluation of the online CSR disclosure, a disclosure index is used. Consistent with other similar studies (Khasharmeh \& Desoky, 2013; Ettredge, et al, 2002; Grudic Kvasic, et al., 2016; Desoky, 2009), an unweighted disclosure index, which treats all items equally with a dichotomous procedure in which an item scores (1) if it is disclosed and (0) if otherwise, was adopted in this study, implying that all items are equal in importance. The final index included 47 items of CSR information categorized into four types of information - environmental (10 items); employee (15 items); community involvement (15 items); and product ( 7 items), according to Khasharmeh \& Desoky's approach (2013). The Khasharmeh \& Desoky's approach was adopted in this study as the CSR disclosure items considered were universal in nature and could be applied to any business entity operating anywhere in the world. 
During the coding process using dichotomous scale, if the CSR information appears several times, it is counted only once. However, if an information relates to several activities, it counts more times (for each disclosure item separately). Proceeding in this way, based on previous research findings (Branco \& Rodriguez, 2006; Hinson, et al., 2010; Grudic Kvasic, et al., 2016), a CSR index was obtained. It should be noted that the described system does not necessarily reflect the quality of CSR activities, but their frequency in the four CSR categories specified in the study.

The data as a result of the content analysis were further analyzed using the following statistical tools: frequency and percentage; weighted mean; ANOVA; Tukey test; and point biserial correlation.

\section{RESULTS AND DISCUSSION}

This part of the paper presents, analyzes, and interprets the data gathered from the website evaluation conducted by the researcher. For clarity of presentation and consistency in the discussion, the data are presented according to the objectives of the study.

\section{Attributes of Publicly-Listed Companies}

It can be gleaned from Table 1 that the top publicly-listed companies in the Philippines regardless of sector have been successfully operating for decades (mean age of 63.53 years old). These companies have medium size market capitalization (mean capitalization of $\mathrm{P} 314.68 \mathrm{~B}$ ) and majority of them have been listed with Philippine Stock Exchange since 20 years ago (mean age as listed company is 26.83 years). Considering their firm attributes, it can be surmised that these companies generally weigh heavily in the country's economy, and further, in Southeast Asia and the world (http://bit.ly/2kBj103). It can be noted also that some of these companies are subsidiaries from a same group. Several of these Philippine corporations, including some of these subsidiaries, are also part of the largest companies in Southeast Asia. Considering the attributes of the top publicly-listed companies in the Philippines, it would be worthy to find out their online CSR disclosure practices as information would be readily available to their stakeholders. While they may practice offline disclosure activities, this study will only present their online disclosure practices.

Table 1: Attributes of Publicly-Listed Companies

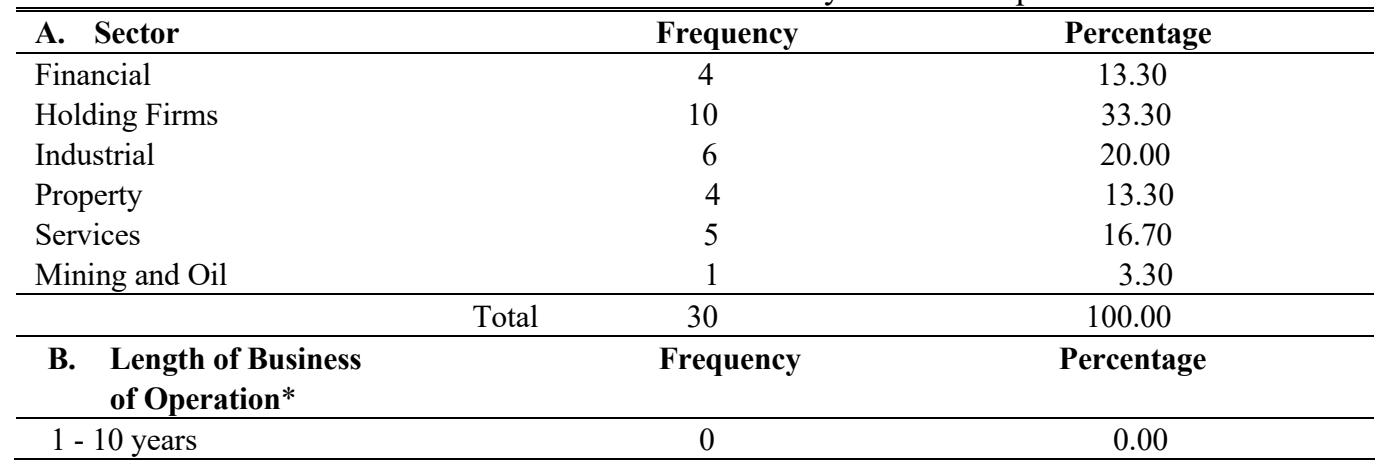




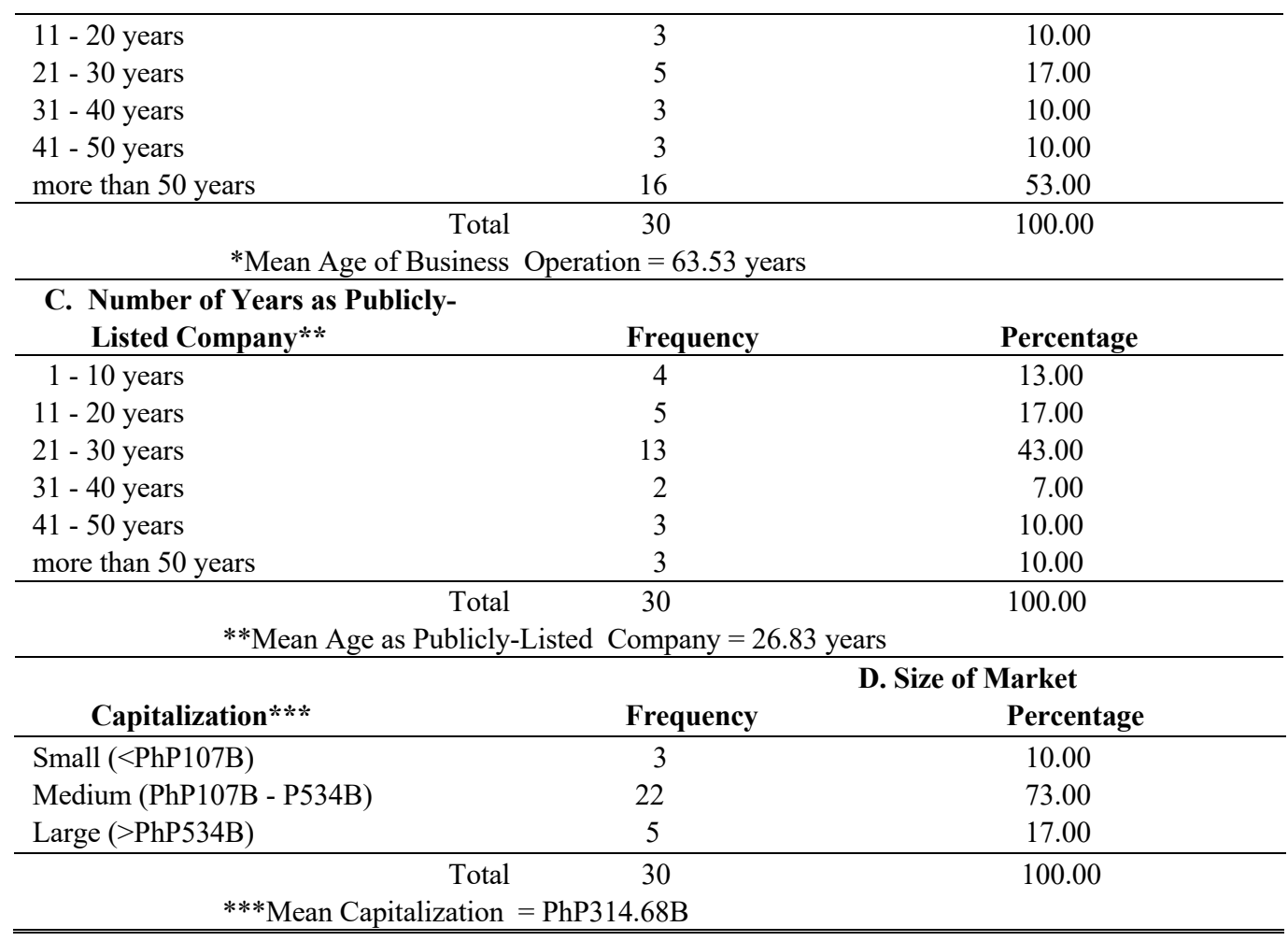

\section{Website Section for CSR Reporting}

It can be noted that all the companies have stand alone section in their corporate websites where CSR activities are disclosed. The condition of CSR reporting, according to Baele (2012), is the presence of a stand alone section on the company's website dealing with topic related to the company's CSR initiatives. According to Grudic Kvasic, et al. (2016), CSR activities may be disclosed through CSR reports that, given the voluntary basis, can testify how the company responsibly acts with honesty and transparency to its stakeholders. CSR reports are known under different names. It can be noted from Table 2 that half of the subject Philippine companies name the CSR report as "CSR" while some others term it as "Sustainability". In this regard, the use of "CSR" or "Sustainability" as heading is considered most popular among top Philippine companies. However, for the purpose of this study, only those CSR activities which were reported in the stand alone website section including all the website links therein (if there are any indicated in the report) were examined and included in the evaluation.

Table 2: Website Section for CSR Reporting

\begin{tabular}{lcc}
\hline \multicolumn{1}{c}{ Website Section } & Frequency & Percentage \\
\hline CSR/ Corporate Social Responsibility & 15 & 50.00 \\
Sustainability & 10 & 33.30 \\
Sustainability \& CSR & 2 & 6.70
\end{tabular}




\begin{tabular}{lccc}
\hline \hline \multicolumn{1}{c}{ Website Section } & Frequency & Percentage \\
\hline Corporate Sustainability \& Reporting & 1 & 3.30 \\
Advocacies & 1 & 3.30 \\
Corporate Citizenship & Total & 1 & 3.30 \\
\hline & Tota & 100.00 \\
\hline \hline
\end{tabular}

\section{Extent of CSR Disclosure}

The content analysis which identified 47 activities in the four CSR category themes served as the basis for the calculation of the CSR disclosure index (Appendix B). Table 3 shows the extent of CSR reporting of the top publicly listed companies in the Philippines. Calculated CSR indexes indicate that among the four category themes, activities related to community involvement, and environment have average level disclosures of information. It can likewise be noted that the levels of disclosures in these two category themes are significantly higher compared with the disclosures of information related to employees, and customers (product), the latter category themes being disclosed poorly. H1, therefore, was accepted. With the variation of disclosures among the four category themes, the overall disclosure index of the subject-companies resulted to 27.93 which is interpreted as below average as to the overall level of CSR disclosure. This implies that the CSR disclosures of Philippine companies need improvement for the benefit of their stakeholders. Relative to the concept of the stakeholder theory, stakeholders expect that there are certain issues and concerns which can be corrected by companies through various CSR-related activities. Thus, the finding further implies that the subject companies should engage more in activities confronting issues of the employees and customers.

It can also be surmised that the low level of CSR reporting of the subject companies maybe similar to the case of Malaysian companies as revealed in the study of Thompson and Zakaria (2004). The previous researchers concluded that the low CSR reporting is due to the absence of recognized reporting framework, lack of government and primary stakeholders' pressure, and lack of perceived benefits that the companies can get from such voluntary disclosures. The findings likewise indicate that Philippine companies are generally prioritizing the reporting of their CSR activities along the category themes of community involvement and environment. This may suggest that companies disclosing more community involvement information intend to enhance their reputation and image with their stakeholders. With the information provided, the companies believe they can strengthen their relationship with the society. The case of Philippine companies is generally similar with companies from other emerging countries like Malaysia (Hassan, et al., 2012) and Kenya (Ponnu \& Okoth, 2009) whose CSR activities are focused more on community involvement rather than any other category theme.

Table 3: Summary of Disclosure Index Scores

\begin{tabular}{lcc}
\hline \multicolumn{1}{c}{ Disclosure Dimension/ Category } & Mean & Verbal \\
& Score & Interpretation \\
\hline Environmental Information (ENV) & 46.67 & Average \\
Employee Information (EMP) & 6.89 & Poor \\
Community Involvement Information (COM) & 52.44 & Average \\
Products Information (PRO) & 5.72 & Poor \\
\hline
\end{tabular}




\begin{tabular}{lll}
\hline \hline \multicolumn{1}{c}{ Disclosure Dimension/ Category } & $\begin{array}{l}\text { Mean } \\
\text { Score }\end{array}$ & $\begin{array}{c}\text { Verbal } \\
\text { Interpretation }\end{array}$ \\
\hline Disclosure Index Score & 27.93 & Below Average \\
\hline \hline Legend: Mean Score and Verbal Interpretation: $1-20=$ Poor; $21-40=$ Below Average; $41-60=$ Average; $61-80$ \\
$=$ Above Average; $81-100=$ Excellent \\
Test of Significant Difference by Disclosure Dimension/Category: $p$-value=7.84E-18; Decision = Highly Significant \\
Tukey Highly Significant Pair of Means: ENV \& EMP;ENV \& PRO; COM \& EMP; COM \& PRO
\end{tabular}

Next to community involvement, it seems that environmental responsibility is also well institutionalized among the Philippine companies. This could be the reason why these companies are reporting their activities on how they respond to protect the environment. It may be also possible that the subject companies operate in industries that have direct impact on the environment. On the other hand, information on CSR activities related to employees and customers (products), being also important dimensions of CSR, are not being prioritized in their voluntary reporting. This is the same result obtained in the study of Ponnu and Okoth (2009) who also found out the low CSR disclosures on the aspect of human resources justifying that companies in Kenya are not paying much attention to their workforce since the business owners believe they can always find qualified personnel in the market should their employees opt to leave at any time. It can also be noted that in contrast to the Philippine companies, counterparts in Gulf Cooperation Council countries favored their customers by reporting product quality information on top of all the CSR items. This means that these companies provide such information to satisfy their customers among any other stakeholders (Khasharmeh \& Desoky, 2013). The present study's finding that CSR information on employees and customers is not being prioritized further confirmed that Philippines companies have provided evidences similar to those in other emerging economies of the world. Md Zaini et al. (2018), in their review of 35 articles about the external factors affecting voluntary CSR disclosures in emerging countries, found out that information on community involvement and environment are the popular categories of voluntary disclosure while human capital or the intellectual capital is considered as the least popular category.

Among the 47 CSR disclosure items, items related to activities related to the community involvement ( 3 items) and environment ( 2 items) are generally disclosed by all companies with percentage disclosure of 80 to 90 percent. On the other hand, one item related to products, three items related to employees, and one item related to community involvement have 0 percent disclosure. Thus, these items are generally not prioritized among the 47 CSR activities identified in the study. The result further explains the popularity of CSR activities employed by Philippine companies relative to their thrusts to community involvement and environment protection programs.

Table 4: List of Highest and Lowest 5 Items of the Online CSR Disclosure

\begin{tabular}{lcc}
\hline \hline \multicolumn{1}{c}{ Top 5 Items } & $\begin{array}{c}\text { Disclosure } \\
\text { Category }\end{array}$ & $\begin{array}{c}\text { Extent of } \\
\text { Disclosure }\end{array}$ \\
\hline 1. Contribution toward community serving program & COM & $90.00 \%$ \\
2. Contribution in the environment protection programs & ENV & $83.33 \%$ \\
3. Conservation of natural resources & ENV & $83.33 \%$ \\
4. Relation with local population & COM & $83.33 \%$ \\
5. Donations to the charity, arts, sports, etc. & COM & $80.00 \%$ \\
\hline \hline
\end{tabular}




\begin{tabular}{lcc}
\hline \hline \multicolumn{1}{c}{ Lowest 5 Items } & $\begin{array}{c}\text { Disclosure } \\
\text { Category }\end{array}$ & $\begin{array}{c}\text { Extent of } \\
\text { Disclosure }\end{array}$ \\
\hline $\begin{array}{l}\text { 1. The company's role in controlling prices and optimizing } \\
\text { profits }\end{array}$ & PRO & $0.00 \%$ \\
2. Recreation clubs and public libraries & EMP & $0.00 \%$ \\
3. Qualifications of the recruited employees & EMP & $0.00 \%$ \\
4. Employee share purchase scheme & EMP & $0.00 \%$ \\
5. Transportation for the employees' children & COM & $0.00 \%$ \\
\hline \hline
\end{tabular}

\section{Relationship of Firm Attributes and CSR Disclosure Index Score}

It can be noted that among the firm attributes, the length of business operation of the publicly listed companies (H3) has shown significant association $(\alpha=0.10)$ with CSR index score. This means that much older companies tend to disclose CSR information compared with relatively younger companies, and therefore $\mathrm{H} 3$ was accepted. This finding jibes with the finding of previous researchers (Hamid, 2004; Branco \& Rodriguez, 2006; Bayoud et al., 2012; Bonson \& Escobar, 2002).

The study also shows that other firm attributes such as industry sector (H2), number of years listed (H4), and market capitalization (H5) are not significantly related with CSR index score. This means that the CSR disclosure index scores is not dependent on these firm attributes.

The above finding that industry sector $(\mathrm{H} 2)$ is not positively related to CSR disclosures contradicts with the results of the two groups of researchers: Bonson and Escobar (2002); and Boesso and Kumar (2007). This, however, supports the findings of Pozniak et al., (2011) and Ramsamy and Ting (2004). Similarly, the finding that listing status (H4) is not a determinant of the CSR disclosures is contrary to the results of the past studies (Pozniak et al., 2011; Hamid, 2004; Bonson \& Escobar, 2002; Bayoud et al., 2012). Lastly, the finding that market capitalization is not a driver of CSR disclosures is also contrary to the conclusion of Abu Sufian's study in 2012.

Table 5: Relationship between Firm Attributes and CSR Disclosure Index Score

\begin{tabular}{llccc}
\hline \multicolumn{1}{c}{$\begin{array}{c}\text { Firm } \\
\text { Attributes }\end{array}$} & \multicolumn{1}{c}{ Hypothesis } & $\begin{array}{c}\text { Computed } \\
\text { Coefficient of } \\
\text { Correlation }\end{array}$ & p-value & $\begin{array}{c}\text { Conclusion } \\
\text { (at } \boldsymbol{\alpha}=\mathbf{0 . 1 0})\end{array}$ \\
\hline Sector & $\begin{array}{l}\text { Industry sector of the } \\
\text { reporting company influences } \\
\text { their CSR disclosure index } \\
\text { (H2) }\end{array}$ & -0.0018 & 0.9923 & Not Significant \\
& $\begin{array}{l}\text { Length of business operation } \\
\text { influences CSR disclosure }\end{array}$ & 0.3312 & 0.0738 & Significant \\
\hline $\begin{array}{l}\text { Length of } \\
\text { Business }\end{array}$ & index score (H3) & & & \\
\hline $\begin{array}{l}\text { Numberation } \\
\text { Years Listed }\end{array}$ & $\begin{array}{l}\text { Number of years listed } \\
\text { influences CSR disclosure } \\
\text { index score (H4) }\end{array}$ & & 0.1737 & Not Significant \\
\hline \hline
\end{tabular}




\begin{tabular}{|c|c|c|c|c|}
\hline $\begin{array}{c}\text { Firm } \\
\text { Attributes }\end{array}$ & Hypothesis & $\begin{array}{c}\text { Computed } \\
\text { Coefficient of } \\
\text { Correlation } \\
\end{array}$ & p-value & $\begin{array}{l}\text { Conclusion } \\
(\text { at } \alpha=0.10)\end{array}$ \\
\hline $\begin{array}{l}\text { Market } \\
\text { Capitalization }\end{array}$ & $\begin{array}{l}\text { Market capitalization } \\
\text { influences CSR disclosure } \\
\text { index score }(\mathrm{H} 4)\end{array}$ & -0.0268 & 0.8880 & Not Significant \\
\hline
\end{tabular}

\section{CONCLUSIONS}

Philippines' top 30 publicly-listed companies are considered pillars of economic development in the country. Their firm attributes can be equated with the best and successful firms in Southeast Asia. It is evident in the study that internet usage in the country for disclosing CSR related information is fully utilized by the companies, with the corporate websites as medium where popular stand alone sections for CSR activities are headed either "CSR" or "Sustainability". The study also concluded that CSR disclosures of these publicly listed companies significantly varies along the four category themes while length of business of operation is considered as the only determinant of CSR disclosures among the firm attributes covered in the study.

The overall online CSR disclosures of Philippines' top companies is below average, thus there is a need to improve the level of reporting especially on information along the category themes of employees and customers (products). It must be considered by companies that even if the CSR disclosures is voluntary in nature, still responsible companies should know that it is an important opportunity of using their CSR reports as a "pro-company" communication report which can eventually provide benefits to them in the long run as their stakeholders become more interested in dealing business with them because of the information they have provided. Moreover, based on stakeholder theory, companies have to engage in a variety of CSR activities to satisfy the expectations of their stakeholders. The study recommended that companies should have periodic updating of the CSR section of their websites for their stakeholders to be informed of their CSR related activities. In doing so, the stakeholders' interest is considered through the provision of timely information.

In order to improve the online CSR reporting of Philippine companies, it is likewise recommended that a recognized reporting framework should be installed. There must be presence of government and stakeholders' pressures for companies to report properly their CSR activities in their corporate websites. Thus, this study could serve as a guide in drawing up policies by concerned government agencies.

\section{REFERENCES}

Abu Sufian, M. (2012). Corporate social responsibility disclosure in Bangladesh. Global Journal of Management and Business Research, 12(14), 149-155.

Amran, A. (2012). Exploring online sustainability disclosure among Malaysian company. Procedia - Social and Behavioral Sciences, 65(0), 761-767. doi.org/10.1016/j.sbspro.2012.11.196. 
ASEAN Up. (2019.) Top 30 companies from the Philippines' PSEi. Retrieved from http://bit.ly/2kBj103.

Baele, A. (2012). The CEO's perception on CSR: A determinant of CSR reporting (Master's thesis, Ghent University, Belgium). Retrieved from https://bit.ly/2LFdaDb.

Barako, D. G., Hancock, P., \& Iszan, H. Y. (2006). Factors influencing voluntary corporate disclosure by Kenyan companies. Corporate Governance: An International Review, 14(2), 107-125.

Bayoud, N. S., Kavanagh, M., \& Slaughter, G. (2012). Factors influencing levels of corporate social responsibility disclosure by Libyan firms: A mixed study. International Journal of Economics and Finance, 4(4). 13-29.

Boesso, G., \& Kumar, K. (2007). Drivers of corporate voluntary disclosure: A framework and empirical evidence from Italy and the United States. Accounting, Auditing \& Accountability Journal, 20(2), 269-296.

Bonson, E., \& Escobar, T. (2002). A survey on voluntary disclosure on the internet: Empirical evidence from 300 European Union companies. The International Journal of Digital Accounting Research, 2(1), 27-51.

Branco, M. C., \& Rodrigues, L. L. (2006). Communication of corporate social responsibility by Portuguese banks. Corporate Communications, 11(3), 232-2248. doi.101.1108/13563280610680821.

Bravo, R., Matute, J., \& Pina, J. M. (2012). Corporate social responsibility as a vehicle to reveal the corporate identity: A study focused on the websites of Spanish financial entities. Journal of Business Ethics, 107(2), 129-146. doi.10.1007/s10551-011-1027-2.

Business World. (2019). SEC issues rules for listed firms' reports on sustainability. Retrieved from https://bit.ly/2m87Xbd.

Castelo, M., \& Lima, L. (2006). Communication of corporate social responsibility by Portuguese banks: A legitimacy theory perspective. Corporate Communications, 11(3), 232-248.

Chapple, W., \& Moon, J. (2005). Corporate social responsibility (CSR) in Asia: A seven-country study of CSR website reporting. Business and Society, 44(4), 415-441.

Desoky, A. (2009). Company characteristics as determinants of internet financial reporting in emerging markets: The case of Egypt. Research in Accounting in Emerging Economies, 9(1), 31-71. doi: 10.1108/S1479-3563(2009)0000009004.

Elsayed, A. N. M. E. (2010). Key determinants of the voluntary adoption of corporate internet reporting and its consequence on firm value: Evidence from Egypt. (Doctoral dissertation, University of Plymouth, United Kingdom). Retrieved from http://bit.ly/37OsaoD.

Erdiaw-Kwasie, M. O., Alam, K., \& Kabir, E. (2017). Modelling corporate stakeholder orientation: Does the relationship between stakeholder background characteristics and corporate social performance matter?. Business Strategy and the Environment, 26(4), 465-479. doi.org/10.1002/bse.1930.

Ettredge, M., Richardson, V., \& Scholz, S. (2002). Dissemination of information for investors at corporate websites. Journal of Accounting and Public Policy, 21, 357-369.

Fukukawa, K., \& Moon, J. (2004). A Japanese model of corporate social responsibility? A study of website reporting. The Journal of Corporate Citizenship, 16(Winter), 45-59.

Garcia, A. A., Arimany-Serrat, N., Salazar, C. U., \& Aliberch, A. S. (2016). Web communication of CSR and financial performance: A study of Catalan meat companies. Intangible Capital, 12(2), 319-419. doi.org/10.3926/ic.590.

Ghazali, N. A. M. (2007). Ownership structure and corporate social responsibility disclosure: Some Malaysian evidence. Corporate Governance, 7(3), 251-266. 
Grudic Kvasic, S., Cerovic, L., \& Olgic Drazenovic, B. (2016). Online corporate social responsibility reporting in the Croatian banking sector. International Public Administration Review. 14(4), 9-26.

Haji, A. A. (2013). Corporate social responsibility disclosures over time: Evidence from Malaysia. Managerial Auditing Journal, 28(7), 4-14.

Hamid, F. Z. A. (2004). Corporate social disclosure by banks and finance companies: Malaysian evidence. Corporate Ownership and Control, 1(4), 118-130.

Hassan, N. H. C., Yusoff, H., \& Yatim, N. (2012). Disclosing social responsibility information via the internet: A study on companies in Malaysia. International Journal of Arts and Commerce, 1(5), 83-96.

Hinson, R., Boateng, R., \& Madichie, N. (2010). Corporate social responsibility activity reportage on bank websites in Ghana. International Journal of Bank Marketing, 18(2), 117-134. doi: $10.15240 /$ tul/001/2015-2-009.

Homayoun, S., Abdul Rahman, R., Johansson, J., \& Malmstrom, M. (2012). Internet corporate social responsibility disclosure among Malaysian listed companies. BIOINFO Financial Management, 2(1), 42-50.

Khasharmeh, H. A., \& Desoky, A. M. (2013). On-line corporate social responsibility disclosures: The case of the Gulf Cooperation Council (GCC) countries. Global Review of Accounting and Finance. 4, 39-64.

Lakatos, E. S., Gazdac, R. M., \& Dan, V. (2012). Using the web by Finnish SME's for corporate social responsibility activities. Advanced Materials Research, 463, 1186-1189.

Md Zaini, S., Samkin, G., Sharma, U., \& Davey, H. (2018). Voluntary disclosure in emerging countries: A literature review. Journal of Accounting in Emerging Economies, 8(1), 2965.

Mohd Ghazali, N. A. (2007). Ownership structure and corporate social responsibility disclosure: Some Malaysian evidence. Corporate Governance, 38(4), 251-266.

Moreno, A., \& Capriotti, P. (2009). Communicating CSR, citizenship and sustainability on the web. Journal of Communication Management, 13(2), 157-175. doi.org/10.1108/13632540910951768.

Patten, D. M. (2002). Give or take on the internet: An examination of the disclosure practices of insurance firm web innovators. Journal of Business Ethics, 36(3), 247-259. doi.10.1023/A:1014009229437.

Ponnu, C. H., \& Okoth, M. O. A. (2009). Corporate social responsibility disclosure in Kenya: The Nairobi stock exchange. African Journal of Business Management, 3(10), 601-608. doi: 10.5897/AJBM09.118.

Porter, M. E., \& Kramer, M. R. (2006). Strategy \& society: The link between competitive advantage and corporate social responsibility. Harvard Business Review, 84(12), 78-92.

Pozniak, L., Ferauge, P., Arnone, L., \& Geerts, A. (2011). Determinants of internet corporate social responsibility communication. Global Journal of Business Research, 5(4), 1-14.

Rahim, N. A. (2016). The extent of online corporate social responsibility (CSR) disclosure: The Malaysian Context. Journal of Global Business and Social Entrepreneurship, 2(5),12-24.

Ramasamy, B., \& Ting, H. W. (2004). A comparative analysis of corporate social responsibility awareness: Malaysian and Singaporean firms. The Journal of Corporate Citizenship, 13, $109-123$.

Rouf, M. A. (2011). The corporate social responsibility disclosure: A study of listed companies in Bangladesh. Business and Economics Research Journal, 2(3), 19-32. 
Said, R., Zainuddin, Y. H., \& Haron, H. (2009). The relationship between corporate social responsibility disclosure and corporate governance characteristics in Malaysian public listed companies. Social Responsibility Journal, 5(2), 212-226.

Sanil, H. S., \& Ramakrishnan, S. (2015). Communicating the corporate social responsibility on the company website: A study conducted on worldwide accredited production certified apparel manufacturers in India. International Journal of Economics and Financial Issues, 5(Special Issue), 52-56.

Sobhani, F. A., Amran, A., \& Zainuddin, Y. (2012). Sustainability disclosure in annual reports and websites: A study of the banking industry in Bangladesh. Journal of Cleaner Production, 23(1), 75-85.

Suwaidan, M. S. (2004). Social responsibility disclosure and corporate characteristics: The case of Jordanian industrial companies. International Journal of Accounting, Auditing and Performance Evaluation, 1(4), 432-447.

Thompson, P., \& Zakaria, Z. (2004). Corporate social responsibility reporting in Malaysia: Progress and prospects. The Journal of Corporate Citizenship. 13(Spring), 125-136.

Wanderley, L. S. O., Lucian, R., Farache, F., \& de Sousa Filho, J. M. (2008). CSR information disclosure on the web: A context-based approach analysing the influence of country of origin and industry sector. Journal of Business Ethics, 82(2), 369-378. doi.10.1007/s10551-008-9892-z. 
Appendix A. Top 30 Companies from the Philippines' PSEi

1. Aboitiz Equity Ventures, Inc.

2. Aboitiz Power Corp.

3. Alliance Global Group, Inc.

4. Ayala Corporation

5. Ayala Land, Inc.

6. Bank of the Philippine Islands

7. BDO Unibank, Inc.

8. DMCI Holdings, Inc.

9. First Gen Corporation

10. Globe Telecom, Inc.

11. GT Capital Holdings, Inc.

12. International Container Terminal Services, Inc.

13. JG Summit Holdings, Inc.

14. Jollibee Foods Corporation

15. LT Group, Inc.

16. Manila Electric Company

17. Megaworld Corporation

18. Metro Pacific Investments Corporation

19. Metropolitan Bank \& Trust Company

20. Petron Corporation

21. Philippine Long Distance Telephone Company

22. Puregold Price Club, Inc.

23. Robinsons Land Corporation

24. Robinsons Retail Holdings, Inc.

25. San Miguel Corporation

26. Security Bank Corporation

27. SM Investments Corporation

28. SM Prime Holdings, Inc.

29. Semirara Mining and Power Corporation

30. Universal Robina Corporation

Source: http://bit.ly/2kBj103 
Appendix B: Items of Information and their Extent of Disclosure

\begin{tabular}{ccc}
\hline \hline Item & $\begin{array}{c}\text { No. of } \\
\text { companies } \\
\text { disclosing } \\
\text { the item }\end{array}$ & $\begin{array}{c}\text { Extent of } \\
\text { disclosure of } \\
\text { the item (\%)* }\end{array}$ \\
\hline
\end{tabular}

\section{A. Environmental Information (ENV)}

1. The company's policy toward the environment 19

63.33

2. Contribution in the environment protection programs 25

83.33

3. Conservation of natural resources

83.33

4. Recycling of plant wastes

36.67

5. Financing and using equipment which protect the environment

33.33

6. Green building

7. Disposal of waste in a proper manner

36.67

8. R \& D for the environment

20.00

9. Compliance with environmental regulations and requirements

10. Energy saving

\section{B. Employee Information (EMP)}

11. Human resource development (e.g. training program/ scheme)

12. Education facilities

13. Health arrangements

10.00

14. Safety arrangements

15. Holidays and vacations

16. Recreation clubs and public libraries

17. Special loan interest rates

18. Labor rights

19. Establishment of training centers

20. Policies for the company's remuneration package/ scheme

21. Number of employees in the company

22. Qualifications of employees recruited

23. Employee share purchase scheme

24. Stability of the workers' job and company's future

\section{Community Involvement Information (COM)}

26. Donations to the charity, arts, sports, etc. 24

80.00

27. Relation with local population

28. Sponsoring education seminars and conference

29. Transportation for the employees' children

30. Establishment of educational institution(s)

31. Medical establishment

32. Corporate gifts

33. Public hall and/or auditorium 


\begin{tabular}{lrr}
\hline \hline 36. Contribution toward community serving program & 23 & 76.67 \\
37. Conducting projects in poor areas & 8 & 26.67 \\
38. Cash rewards & 16 & 53.33 \\
39. Financial assistance & 2 & 6.67 \\
40. Participating and financing community celebration & & \\
& & 6.67 \\
D. Products Information (PRO) & 2 & 3.33 \\
41. Developments related to the company's products including & 1 & 6.67 \\
packaging & 2 & 10.00 \\
42. Research projects set up by the company to improve its product in & 3 & 0.00 \\
any way & 0 & 6.67 \\
43. Product quality & 2 & 6.67 \\
44. Responsiveness to customer complaints & 2 & \\
45. The company's role in controlling prices and optimizing profits & & \\
46. Compliance with customer protection legislation & & \\
47. Customer service programs, market, research, product, warranty, & \\
educate customers about goods being sold & & \\
\hline \hline
\end{tabular}

*Percentage of companies disclosing the items to the total sampled companies of 30 . 